\title{
Determinants of fruits, vegetables, and ultra-processed foods consumption among infants
}

\author{
Determinantes do consumo de frutas, hortaliças e de alimentos \\ ultraprocessados entre lactentes
}

Adriana Passanha (https://orcid.org/0000-0001-6659-1251) ${ }^{1}$

Maria Helena D’Aquino Benício (https://orcid.org/0000-0003-1851-1178) ${ }^{1}$

Sonia Isovama Venâncio (https://orcid.org/0000-0001-7147-3292) ${ }^{2}$

${ }^{1}$ Departamento de Nutrição, Faculdade de Saúde Pública, Universidade de São Paulo. Av. Doutor Arnaldo 715, Cerqueira César. 01246904 São Paulo SP Brasil. adriana.passanha@ gmail.com

${ }^{2}$ Núcleo de Evidências, Instituto de Saúde, Secretaria de Estado da Saúde de São Paulo. São Paulo SP Brasil.
Abstract The objective was to evaluate the influence of individual and contextual determinants on infant's consumption of fruits and vegetables (FV), and ultra-processed foods (UPF). The data was obtained from the Survey of Prevalence of Breastfeeding in Brazilian Municipalities, 2008. A representative sample of 14,326 infants 6-11.9 months old, from seventy-five municipalities of São Paulo state was evaluated. The influence of determinants on FV and UPF consumption was analyzed using Poisson multilevel regression. Mother's educational level and maternal age had positive dose-response effect for the consumption of FV ( $p$ trend $<0.001)$ and negative for UPF ( $p$ trend $<0.001)$. Infants of multiparous women and those who received outpatient care in public medical system showed lower prevalence of $F V$ ( $p$ $<0.001$ for both) and higher prevalence of UPF (respectively, $p<0.001$ and $p=0.001$ ). Moreover, the contextual variable related to population size indicated that the prevalence of consumption of $F V$ decreased $(p<0.001)$ and UPF increased $(p=$ 0.081 ) with decreased population size. Therefore, infants born to women with low education levels, who received outpatient care in the public health network, and who reside in small municipalities should be prioritized for educational programs related to feeding practices.

Key words Infant Nutrition, Food consumption, Multilevel Analysis
Resumo O objetivo foi analisar a influência de determinantes individuais e contextuais sobre o consumo de frutas, legumes e verduras (FLV) e de alimentos ultraprocessados (AUP) entre lactentes. Estudo com amostra representativa de 14.326 lactentes com idade entre 6-11,9 meses de 75 municípios do estado de São Paulo participantes da Pesquisa de Prevalencia de Aleitamento Materno em Municípios Brasileiros, de 2008. A influência dos determinantes sobre o consumo de FLV e de AUP foi avaliada por regressão de Poisson multinível. A escolaridade e faixa etária maternas mostraram efeito dose-resposta positivo para o consumo de FLV ( $p$ de tendência $<0,001$ ), e negativo para AUP ( $p$ de tendência $<0,001)$. O consumo de FLV foi menos prevalente entre filhos de multiparas ( $p$ $<0,001)$ e entre aqueles acompanhados no sistema público de saúde ( $p<0,001)$; porém, estes dois grupos apresentaram maiores prevalências de consumo de AUP (respectivamente: $p<0,001$ e $p$ =0,001). Ainda, a variável contextual referente ao porte populacional mostrou relação dose-resposta positiva para FLV ( $p<0,001)$, e negativa para AUP $(p=0,081)$. Destacam-se grupos que deveriam ser priorizados nas ações nutricionais educativas sobre alimentação de lactentes.

Palavras-chave Nutrição Infantil, Consumo de Alimentos, Análise Multinível 


\section{Introduction}

Children undergo accelerated development during the first years of life, and nutrition plays a fundamental role in this process ${ }^{1,2}$. Until six months old, an infant's nutritional needs are met by exclusive breastfeeding; after this, the infant must also start consuming foods. ${ }^{1}$ Inadequate dietary practices or nutritional deficiencies in this period can cause serious harm to the infant's health, including increased of morbidity and mortality ${ }^{1,2}$. Moreover, this period when other foods are first added to the diet begin to form infant's eating habits and food preferences, which will continue into their adult life ${ }^{3}$; thus, preference of healthy foods and avoidance of unhealthy foods is essential (WHO, 2003)4.

Fruits and vegetables (FV) are the main food sources of vitamins, minerals, and fibers ${ }^{2,4}$, which are essential nutrients for healthy and adequate development. Furthermore, according to the Dietary Guidelines for the Brazilian population ${ }^{5}$, FV are part of the natural or minimally processed foods group, which are the basis of nutritious, delicious, and proper diets. On the other hand, ultra-processed foods (UPF), according to the NOVA classification, which categorizes foods based on the nature, extent, and purpose of their processing $^{6}$, are formulations mostly of cheap industrial sources of dietary energy, high in unhealthy types of fat, refined starches, free sugars, salt, and additives which make them hyper-palatable and attractive. UPF include cookies, icecreams, candies, soft drinks, sweetened, packaged snacks, as well as "instant" soups and noodles $5^{5,6}$. Offering UPF in the first years of life can harm the quality of the diet and decrease the consumption of healthy foods ${ }^{3}$.

Children under one year do not have the autonomy to make their own food choices and depend on what they are offered; therefore, it is important to know the determinants of infant food consumption. Several individual, social, and environmental factors have been found to influence food consumption ${ }^{7}$. Thus, the objective of this study was to evaluate the influence of individual and contextual determinants on the consumption of FV and UPF among infants.

\section{Methods}

This cross-sectional study was based on information from municipalities of São Paulo that participated of the Survey of Breastfeeding Prevalence in Brazilian Municipalities (Pesquisa de Prevalência de Aleitamento Materno em Municípios Brasileiros) from 2008 (SBP-2008), conducted during the second stage of a broad immunization campaign conducted in that year ${ }^{8}$. Details of the inclusion and exclusion criteria of infants and municipalities evaluated in this study have been described elsewhere?.

The outcomes of this study were: "consumption of FV" - concomitant consumption of fruits and vegetables (yes/no) - and "consumption of UPF" - consumption of any of the following foods: industrialized juices, industrialized coconut water, soft drinks, crackers, cookies, packaged snacks (yes/no) ${ }^{5,6}$. The SBP-2008 used current status of infant feeding to describe infant feeding practices in order to minimize memory bias. The covariates of interest corresponded to the characteristics of the infants (age: in full days; sex: male or female; birth weight: $<2500 \mathrm{~g}, 2500$ to $3000 \mathrm{~g}$, $\geq 3000$ g; place where outpatient care occurred: private or public), and characteristics of the mothers (educational level in years of schooling: $\geq 12,9$ to 12 , and $\leq 8$; age group: $\geq 35$ years, 20 to 35 years, $<20$ years; parity: primiparous or multiparous; work status: working outside the home or not working outside the home), which were the individual determinants of infant feeding. Moreover, a contextual variable was included: the population size of the municipality (in number of inhabitants: $\geq 1$ million, 100 thousand to 1 million, 15 to 100 thousand, $<15$ thousand).

The influence of individual and contextual determinants for each outcome was evaluated by multilevel Poisson regression. Poisson regression was used because it produced good point and interval estimates of Prevalence Ratio (PR) and because it is one of the best options for studies with binary outcomes ${ }^{10}$. Multilevel analysis was performed considering the hierarchical organization of infant population in relation to their characteristics and to the maternal characteristics (Level 1) in each municipality (Level 2), and the existence of intragroup correlation. For the inclusion of the individual variables in the model, the hierarchical approach was used, as can be seen in Figure 1. In this strategy, the hierarchical approach of independent variables is established in a conceptual framework, and the criteria to select these variables does not consider only the statistical aspect but requires knowledge of biological and social determinants as well as temporal precedence. The hierarchical approach is maintained during data analysis, allowing the selection of variables strongly associated with the 


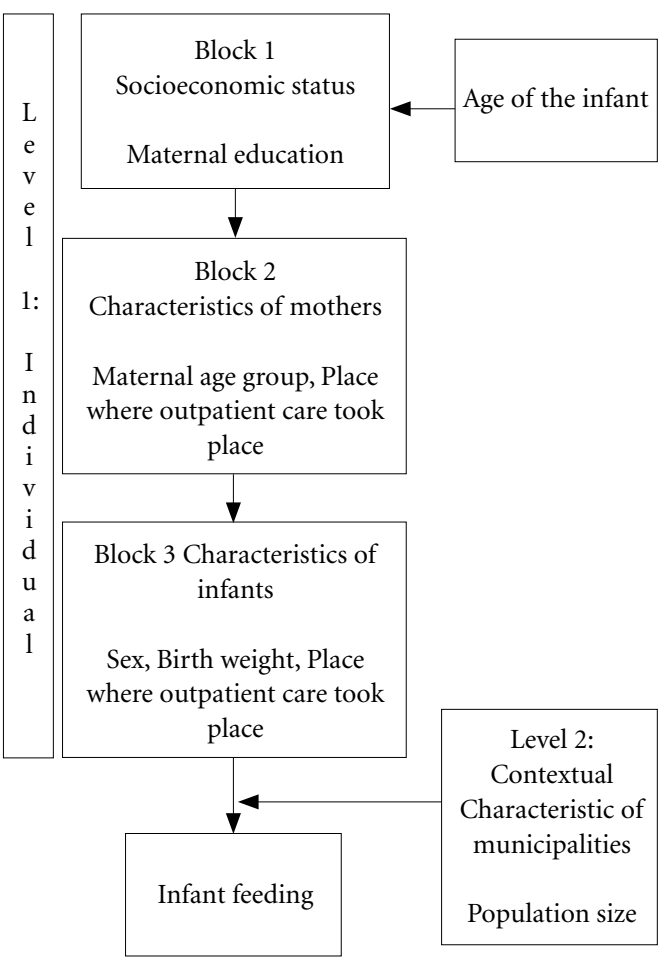

Figure 1. Conceptual framework for investigation of individual and contextual determinants of infant feeding.

outcome of interest ${ }^{11}$. It was assumed that the outcome would be influenced by Level 1 variables, which were grouped into three blocks ${ }^{12}$ :

1- Socioeconomic status: represented by maternal education level;

2- Characteristics of mothers: maternal age group, parity, and employment status;

3- Characteristics of infants: sex, birth weight, and place where outpatient care occurred.

After inclusion of Level 1 variables, the Level 2 variable was inserted: population size of the municipality. The selection of the variables that composed the final model was performed as follows: maternal education was introduced in the first stage of the modeling, and adjusted only by the age of the infant (Block 1); in the next two stages, those related to characteristics of mothers (Block 2) and infants (Block 3) were inserted; the inclusion of the contextual variable was performed during the last stage of modeling. The variables with $\mathrm{p}<0.20$ in the adjust analysis for infant age were considered adjustment variables and were maintained in the model even though they lost statistical significance with the inclusion of the variables of the lower blocks. Variables with more than two categories were introduced into the model in dummy format.

The SBP-2008 is a research done with complex probabilistic sampling and, therefore, requires specific procedures for its analysis. All analyzes of this study considered the complex structure of the sample (using the svy command) and were performed using the Stata/SE 14.1 software.

The variables which presented PR values between 0 and 1 were interpreted as factors that decrease the prevalence of the outcomes; PR values $>1$ were interpreted as factors that increase their prevalence. The association between the study factor and outcome was considered statistically significant when $\mathrm{p}<0.05$. The assessment of fit quality of the multilevel model was verified by the -2loglikelihood test. For the multilevel analysis, the fixed effects/random intercept model was performed as described by SNIJDERS and BOSKER $^{13}$. The measurement of the effect of the individual factors $(\mathrm{b} 1, \mathrm{~b} 2 \ldots)$ is assumed to be constant in all the contexts (fixed portion), and any variation of contextual order falls on the intercept (b0).

This article is based on the doctoral thesis titled "Food consumption of infants from the state of São Paulo, Brazil, in the second semester of life: Survey of Breastfeeding Prevalence in Brazilian Municipalities, 2008", which was approved by the Ethics Committee of the School of Public Health of the University of São Paulo. All subjects gave their verbal consent for the questionnaire to be applied.

\section{Results}

Table 1 presents the characterization of the studied population, the proportion of FV and UPF consumption according to these characteristics, and the results of the analysis adjusted by the age of the infant. More than half of mothers had nine to 12 years of education $(52.4 \%)$ and almost $3 / 4$ of women were 20 to 35 years of age $(74.8 \%)$. The majority of the infants received outpatient care in the public health network $(60.3 \%)$. The percentage of infants born in municipalities with more than 100 thousand inhabitants was $54.6 \%$.

The prevalence of FV consumption was $70.6 \%$; with $75.7 \%$ consuming fruit and $91.2 \%$ vegetable. The prevalence of UPF consumption 
Table 1. Proportion of the consumption of fruits and vegetables and of ultra-processed foods among infants, and the underlying Prevalence Ratios. State of São Paulo, Brazil, 2008.

\begin{tabular}{|c|c|c|c|c|c|c|c|}
\hline \multirow{2}{*}{ Variable } & \multirow{2}{*}{$\mathbf{N}$} & \multicolumn{3}{|c|}{ Fruits and Vegetables } & \multicolumn{3}{|c|}{ Ultra-processed foods } \\
\hline & & $\%$ & $\mathrm{PR}^{\star}(95 \% \mathrm{CI})$ & $\mathbf{p}$ & $\%$ & $\mathrm{PR}^{\star}(95 \% \mathrm{CI})$ & $\mathbf{p}$ \\
\hline Age group of the infants (months) & & & & $<0.001^{\dagger}$ & & & $<0.001^{\dagger}$ \\
\hline $6 \mid-7$ & 2649 & 62.6 & 1 & & 52.0 & 1 & \\
\hline $7 \mid-8$ & 2370 & 67.3 & $1.07(1.02 ; 1.13)$ & & 65.4 & $1.26(1.18 ; 1.34)$ & \\
\hline $8 \mid-9$ & 2288 & 69.1 & $1.11(1.06 ; 1.16)$ & & 75.2 & $1.45(1.36 ; 1.54)$ & \\
\hline $9 \mid-10$ & 2228 & 70.2 & $1.12(1.06 ; 1.18)$ & & 78.8 & $1.52(1.43 ; 1.61)$ & \\
\hline $10 \mid-11$ & 2244 & 69.6 & $1.11(1.06 ; 1.17)$ & & 83.4 & $1.60(1.51 ; 1.71)$ & \\
\hline $11 \mid-12$ & 2547 & 71.2 & $1.14(1.08 ; 1.19)$ & & 86.5 & $1.66(1.57 ; 1.77)$ & \\
\hline $\begin{array}{l}\text { Maternal education (years of } \\
\text { schooling) }\end{array}$ & & & & $<0.001^{\dagger}$ & & & $<0.001^{\dagger}$ \\
\hline$\geq 12$ & 1733 & 82.1 & 1 & & 61.4 & 1 & \\
\hline $9 \mid-12$ & 6057 & 71.2 & $0.87(0.83 ; 0.90)$ & & 73.8 & $1.20(1.13 ; 1.28)$ & \\
\hline$\leq 8$ & 3767 & 57.4 & $0.70(0.66 ; 0.74)$ & & 76.9 & $1.25(1.17 ; 1.33)$ & \\
\hline Maternal age group (years) & & & & $<0.001^{\dagger}$ & & & $<0.001^{\dagger}$ \\
\hline$\geq 35$ & 1438 & 72.4 & 1 & & 67.5 & 1 & \\
\hline $20 \mid-35$ & 8754 & 68.2 & $0.94(0.91 ; 0.98)$ & & 72.7 & $1.08(1.03 ; 1.13)$ & \\
\hline$<20$ & 1508 & 61.4 & $0.85(0.80 ; 0.91)$ & & 79.4 & $1.20(1.14 ; 1.26)$ & \\
\hline Parity & & & & $<0.001$ & & & 0.010 \\
\hline Primiparous & 5924 & 70.4 & 1 & & 71.8 & 1 & \\
\hline Multiparous & 5690 & 64.8 & $0.92(0.89 ; 0.95)$ & & 74.2 & $1.03(1.01 ; 1.06)$ & \\
\hline Work status & & & & $<0.001$ & & & 0.017 \\
\hline Working outside the home & 3722 & 76.0 & 1 & & 71.5 & 1 & \\
\hline Not working outside the home & 7663 & 63.9 & $0.84(0.82 ; 0.87)$ & & 74.2 & $1.04(1.01 ; 1.08)$ & \\
\hline Sex & & & & 0.779 & & & 0.238 \\
\hline Male & 7200 & 68.2 & 1 & & 72.8 & 1 & \\
\hline Female & 7126 & 68.4 & $1.00(0.98 ; 1.03)$ & & 73.7 & $1.02(0.99 ; 1.04)$ & \\
\hline Birth weight (grams) & & & & $0.836^{\dagger}$ & & & $0.002^{\dagger}$ \\
\hline$<2500$ & 1232 & 67.8 & 1 & & 70.8 & 1 & \\
\hline $2500 \mid-3000$ & 3295 & 68.6 & $1.01(0.96 ; 1.07)$ & & 72.4 & $1.03(0.99 ; 1.08)$ & \\
\hline$\geq 3000$ & 8898 & 68.3 & $1.01(0.96 ; 1.06)$ & & 73.4 & $1.06(1.01 ; 1.10)$ & \\
\hline Place where outpatient care occurred & & & & $<0.001$ & & & $<0.001$ \\
\hline Private & 5310 & 77.2 & 1 & & 68.0 & 1 & \\
\hline Public & 8432 & 62.9 & $0.81(0.78 ; 0.85)$ & & 76.7 & $1.12(1.07 ; 1.17)$ & \\
\hline $\begin{array}{l}\text { Population size (number of } \\
\text { inhabitants) }\end{array}$ & & & & $<0.001^{\dagger}$ & & & $0.056^{\dagger}$ \\
\hline$\geq 1$ million & 1752 & 73.6 & 1 & & 66.4 & 1 & \\
\hline 100 thousand $\mid-1$ million & 6073 & 73.9 & $1.00(0.95 ; 1.05)$ & & 71.6 & $1.07(1.01 ; 1.13)$ & \\
\hline $15 \mid-100$ thousand & 5349 & 67.0 & $0.91(0.86 ; 0.96)$ & & 73.9 & $1.10(1.05 ; 1.15)$ & \\
\hline$<15$ thousand & 1152 & 56.8 & $0.77(0.67 ; 0.88)$ & & 75.6 & $1.13(1.05 ; 1.20)$ & \\
\hline
\end{tabular}

PR: Prevalence Ratio. 95\%CI: 95\% Confidence Interval. Fruits and vegetables: concomitant consumption of fruits and vegetables; Ultra-processed foods: consumption of any one of the following foods: industrialized juice, industrialized coconut water, soft drink, cracker, cookie, packaged snack. ${ }^{*} \mathrm{PR}$ values adjusted by age of the infant. ${ }^{\dagger} \mathrm{p}$ of linear trend. Values of $\mathrm{p}<0.20$ are presented in bold.

was $71.5 \%$. Among these, foods with the highest frequency of consumption were crackers/cookies/packaged snacks: $67.4 \%$ (data not shown in the tables).

Consumption of both FV and UPF increased as the age of the infant increased. Consumption of FV decreased and UPF increased when maternal education, mother's age, and population size were lower. The consumption of UPF was higher with increased of the birth weight. Infants born to multiparous mothers, infants born to stay-athome mothers, and infants who received outpa- 
tient care in the public health network consumed less FV and more UPF (Table 1).

Tables 2 and 3 provide the results of multilevel analysis. The lower the mother's education level or mother's age, the lower the consumption of FV and the higher the consumption of UPF ( $p$ trend $<0.001$ for both variables in relation to both outcomes). The consumption of FV was less prevalent among infants born to multiparous mothers ( $\mathrm{p}<$
0.001) and among infants whose outpatient care occurred in the public health network $(\mathrm{p}<0.001)$; however, these infants presented higher prevalence of UPF consumption (respectively: $p<0.001$ and $\mathrm{p}=0.001 ; \mathrm{p}$ values not shown in the tables).

Tables 2 and 3 also indicate that infants born to women who did not work outside the home had a lower prevalence of FV consumption ( $\mathrm{p}<$ 0.001 ), and that work status lost statistical sig-

Table 2. Multilevel analysis: individual and contextual determinants of the consumption of fruits and vegetables among infants, and the underlying adjusted Prevalence Ratios. State of São Paulo, Brazil, 2008.

\begin{tabular}{|c|c|c|c|c|}
\hline & \multicolumn{4}{|c|}{ Fruits and Vegetables } \\
\hline & Model 1* & Model $2^{\dagger}$ & Model $3^{\ddagger}$ & Model $4^{\S}$ \\
\hline Fix effect - Constant & $0.65(0.60 ; 0.71)$ & $0.77(0.69 ; 0.84)$ & $0.78(0.70 ; 0.86)$ & $0.82(0.74 ; 0.92)$ \\
\hline \multicolumn{5}{|l|}{ Block 1, Hierarchical level 1} \\
\hline \multicolumn{5}{|c|}{ Maternal education (years of schooling) } \\
\hline$\geq 12$ & 1 & - & - & - \\
\hline $9 \mid-12$ & $0.87(0.83 ; 0.90)$ & - & - & - \\
\hline$\leq 8$ & $0.70(0.66 ; 0.74)$ & - & - & - \\
\hline \multicolumn{5}{|l|}{ Block 2, Hierarchical level 1} \\
\hline \multicolumn{5}{|l|}{ Maternal age group (years) } \\
\hline$\geq 35$ & - & 1 & - & - \\
\hline $20 \mid-35$ & - & $0.91(0.87 ; 0.95)$ & - & - \\
\hline$<20$ & - & $0.85(0.80 ; 0.92)$ & - & - \\
\hline \multicolumn{5}{|l|}{ Parity } \\
\hline Primiparous & - & 1 & - & - \\
\hline Multiparous & - & $0.95(0.92 ; 0.97)$ & - & - \\
\hline \multicolumn{5}{|l|}{ Work status } \\
\hline Working outside the home & - & 1 & - & - \\
\hline Not working outside the home & - & $0.90(0.87 ; 0.93)$ & - & - \\
\hline \multicolumn{5}{|l|}{ Block 3, Hierarchical level 1} \\
\hline \multicolumn{5}{|l|}{ Birth weight (grams) } \\
\hline$<2500 \mathrm{~g}$ & - & - & - & - \\
\hline $2500 \mid-3000 \mathrm{~g}$ & - & - & - & - \\
\hline$\geq 3000$ & - & - & - & - \\
\hline \multicolumn{5}{|l|}{ Place where outpatient care occurred } \\
\hline Private & - & - & 1 & - \\
\hline Public & - & - & $0.89(0.85 ; 0.92)$ & - \\
\hline \multicolumn{5}{|l|}{ Hierarchical level 2} \\
\hline \multicolumn{5}{|l|}{$\begin{array}{l}\text { Population size (number of } \\
\text { inhabitants) }\end{array}$} \\
\hline$\geq 1$ million & - & - & - & 1 \\
\hline 100 thousand $\mid-1$ million & - & - & - & $1.01(0.96 ; 1.06)$ \\
\hline $15 \mid-100$ thousand & - & - & - & $0.93(0.89 ; 0.98)$ \\
\hline$<15$ thousand & - & - & - & $0.80(0.71 ; 0.90)$ \\
\hline Random effect - Constant & $\begin{array}{r}0.0000202(5.6 \mathrm{e}- \\
116 ; 7.3 \mathrm{e}+105)\end{array}$ & $\begin{array}{r}6.63 e-35(6.47 e- \\
36 ; 6.80 e-34)\end{array}$ & $\begin{array}{r}4.10 \mathrm{e}-35(1.71 \mathrm{e}- \\
35 ; 9.85 \mathrm{e}-35)\end{array}$ & $\begin{array}{r}2.63 \mathrm{e}-36(2.84 \mathrm{e}- \\
37 ; 2.43 \mathrm{e}-35)\end{array}$ \\
\hline -2 loglikelihood & 9916.0592 & 9477.6902 & 9174.0504 & 9159.5564 \\
\hline
\end{tabular}


Table 3. Multilevel analysis: individual and contextual determinants of the consumption of ultra-processed foods among infants, and the underlying adjusted Prevalence Ratios. State of São Paulo, Brazil, 2008.

\begin{tabular}{|c|c|c|c|c|}
\hline & \multicolumn{4}{|c|}{ Ultra-processed foods } \\
\hline & Model $1^{\star}$ & Model $2^{\dagger}$ & Model $3^{\ddagger}$ & Model $4^{\S}$ \\
\hline Fix effect - Constant & $0.27(0.24 ; 0.30)$ & $0.24(0.21 ; 0.28)$ & $0.24(0.20 ; 0.27)$ & $0.22(0.19 ; 0.25)$ \\
\hline \multicolumn{5}{|l|}{ Block 1, Hierarchical level 1} \\
\hline \multicolumn{5}{|l|}{$\begin{array}{l}\text { Maternal education (years of } \\
\text { schooling) }\end{array}$} \\
\hline$\geq 12$ & 1 & - & - & - \\
\hline $9 \mid-12$ & $1.20(1.13 ; 1.28)$ & - & - & - \\
\hline$\leq 8$ & $1.25(1.17 ; 1.33)$ & - & - & - \\
\hline \multicolumn{5}{|l|}{ Block 2, Hierarchical level 1} \\
\hline \multicolumn{5}{|l|}{ Maternal age group (years) } \\
\hline$\geq 35$ & - & 1 & - & - \\
\hline $20 \mid-35$ & - & $1.09(1.04 ; 1.14)$ & - & - \\
\hline$<20$ & - & $1.20(1.14 ; 1.26)$ & - & - \\
\hline \multicolumn{5}{|l|}{ Parity } \\
\hline Primiparous & - & 1 & - & - \\
\hline Multiparous & - & $1.05(1.02 ; 1.08)$ & - & - \\
\hline \multicolumn{5}{|l|}{ Work status } \\
\hline Working outside the home & - & 1 & - & - \\
\hline Not working outside the home & - & $1.00(0.97 ; 1.04)$ & - & - \\
\hline \multicolumn{5}{|l|}{ Block 3, Hierarchical level 1} \\
\hline \multicolumn{5}{|l|}{ Birth weight (grams) } \\
\hline$<2500 \mathrm{~g}$ & - & - & 1 & - \\
\hline $2500 \mid-3000 \mathrm{~g}$ & - & - & $1.02(0.98 ; 1.07)$ & - \\
\hline$\geq 3000$ & - & - & $1.05(1.01 ; 1.10)$ & - \\
\hline \multicolumn{5}{|l|}{ Place where outpatient care occurred } \\
\hline Private & - & - & 1 & - \\
\hline Public & - & - & $1.07(1.03 ; 1.11)$ & - \\
\hline \multicolumn{5}{|l|}{ Hierarchical level 2} \\
\hline \multicolumn{5}{|c|}{ Population size (number of inhabitants) } \\
\hline$\geq 1$ million & - & - & - & 1 \\
\hline 100 thousand $\mid-1$ million & - & - & - & $1.07(1.00 ; 1.14)$ \\
\hline $15 \mid-100$ thousand & - & - & - & $1.09(1.03 ; 1.15)$ \\
\hline$<15$ thousand & - & - & - & $1.12(1.04 ; 1.20)$ \\
\hline Random effect - Constant & $\begin{array}{r}1.05 \mathrm{e}-35(4.42 \mathrm{e}- \\
41 ; 2.50 \mathrm{e}-30)\end{array}$ & $\begin{array}{r}2.05 \mathrm{e}-35(1.90 \mathrm{e}- \\
42 ; 2.20 \mathrm{e}-28)\end{array}$ & $\begin{array}{r}2.58 \mathrm{e}-36(3.90 \mathrm{e}- \\
37 ; 1.71 \mathrm{e}-35)\end{array}$ & $\begin{array}{r}1.43 e-35(1.43 e- \\
35 ; 5.59 e-35)\end{array}$ \\
\hline-2 loglikelihood & 10443.094 & 9976.5684 & 9256.8884 & 9255.9278 \\
\hline
\end{tabular}

nificance in the multiple analysis for UPF consumption. The prevalence of UPF consumption tended to increase with increased birth weight $(\mathrm{p}=0.004)$. Furthermore, despite the effect of the individual variables, the contextual variable related to the population size exhibited a posi- tive dose-response relationship for FV ( $p$ trend $<0.001$ ) and negative relationship for UPF ( $\mathrm{p}$ trend $=0.081 ; \mathrm{p}$ values not shown in the tables). Although population size did not reach statistical significance for the UPF consumption, its value was close to the established cut-off point. 


\section{Discussion}

The prevalence of consumption of FV was lower and UPF was higher in infants whose mothers had low education, were younger, were multiparous, as well as in infants who received outpatient care in the public health network and those who were born in small municipalities. The FV consumption was also lower for infants with stayat-home mothers, and UPF consumption higher among those who were born heavier.

Food patterns have changed in several countries, including Brazil. The changes that have occurred over the last decades include stagnate consumption of $\mathrm{FV}^{14,15}$ and increased consumption of UPF ${ }^{16,17}$. This is a concern because foods that have high energy density but are poor in fiber, vitamins, and minerals - such as UPF - tend to decrease the consumption of foods with lower energy density and higher amounts of micronutrients and fibers - such as $\mathrm{FV}^{18}$. In addition, UPF are often not just consumed between the main meals, but replace them ${ }^{16}$, which makes their consumption even more worrying, especially among infants. UPF are offered to young children because they are often practical, inexpensive, and long-lasting, or due to advertising of these products, which involve alleged advantages compared to other foods - such as "made with selected ingredients" or "addition of vitamins and minerals" - increasing the consumer's belief that they are healthy and nutritious ${ }^{5}$.

Approximately $30 \%$ of the evaluated infants did not consume FV, about $1 / 4$ did not consume fruits, and almost $10 \%$ did not consume vegetables. On the other hand, the consumption of UPF among the infants studied in São Paulo was high: more than $70 \%$ consumed this type of food. Data from II SBP indicate that consumption of FV was absent in almost $30 \%$ of Brazilian infants 6-8.9 months old, and in about $20 \%$ of those 9-11.9 months old ${ }^{19}$. The survey also found that, for the 6-8.9 months age group, $4.9 \%$ of infants had eaten soft drinks and $46.4 \%$ had crackers/packaged snacks; for those with 9-11.9 months, these percentages increase to $11.6 \%$ and $71.7 \%$, respectively ${ }^{19}$. Jaime et al. ${ }^{20}$, who evaluated data from the National Health Survey, found that $1 / 3$ of the Brazilian infants under two years old had consumed soft drinks, while $60.8 \%$ had consumed cookies, crackers, or cakes, and found that infants in the Southeast presented higher prevalence of consumption of such food than the country as a whole. The consumption of UPF is harmful to a child's health and may be associated with ane- mia, overweight, chronic non-communicable diseases, and food allergies ${ }^{4,21-24}$, as well as high amounts of sodium, sugar, fats, and artificial additives $^{5,6}$. In addition, FV are sources of vitamins and minerals, which are essential for the proper development and supply an organism with fibers and water, helping to maintain health ${ }^{2,4}$. Step 7 of the Dietary Guidelines for children under two years old - based on the World Health Organization guidelines - recommends that daily consumption of FV should be stimulated beginning at six months old. Step 8 of the material explains that foods considered unhealthy - such as sugar, coffee, canned foods, fried foods, soft drinks, candies, packaged snacks, and other confectioneries - should be avoided in the first year of life ${ }^{4}$.

Infants born to women with lower educational levels presented lower prevalence of FV consumption and higher prevalence of UPF consumption. Studies in the United Kingdom ${ }^{25,26}$ that evaluated different dietary patterns of infants using principal component analysis found an increase in the diet pattern score for healthy foods - including FV - with increased maternal education, and an increase in the dietary pattern characterized by unhealthy foods - such as fried foods, desserts, and packaged snacks - with the decreasing of this variable. Other studies, carried out in Brazil, found a positive association between increased maternal education and increased consumption of FV by infants ${ }^{27,28}$, and higher consumption of foods such as processed juices, soft drinks, coffee, and sweetened foods among infants born to mothers with no formal education $^{29}$. Education is an important factor representing the socioeconomic condition ${ }^{12}$, and maternal education is an important facilitating factor for child nutrition and development worldwide $^{30}$. Content of educational messages may not be comprehensible to mothers with less education; therefore, improving and strengthening instruction programs for mothers with low levels of education and encouraging the improvement of maternal education levels are strategies that may help to reduced consumption of UPF among young children.

The stagnation of FV and increased UPF in the caloric participation of the diet have occurred more significantly among the low-income population ${ }^{14,17}$. Although in Brazil the cost of diets based on UPF is higher than that of diets based on natural or minimally processed foods ${ }^{31}$, fruits and vegetables are often priced high ${ }^{32}$ and unhealthy foods can be found with increasingly affordable $\operatorname{cost}^{33}$. This shows that the socioeco- 
nomic condition exerts an important influence on food consumption. Therefore, measures to regulate the relative price of food, such as reducing the price of $\mathrm{FV}^{32}$ and a high tax on high energy dense foods ${ }^{34}$ could lead to positive changes in the eating habits of infants and the population in general.

The prevalence of FV consumption was lower and UPF higher among younger mothers. Studies have found a positive association between increased maternal age and increased consumption of FV by infants ${ }^{27,35}$, as well as association between increased maternal age and diets characterized by more healthy foods ${ }^{25,26}$. Other studies have observed that lower maternal age was associated with diets characterized by unhealthy foods $^{25,36}$. In the city of Curitiba, PR, Brazil, the proportions of adolescent mothers who offered sweetened beverages, soft drinks, and crackers/ packaged snacks to their children were higher than those found for adult mothers ${ }^{37}$. Adolescent eating habits are rarely considered adequate, because they tend to reject the dietary habits of their family and adopt habits of their peer group, which would negatively influence the feeding of their children; therefore, many adolescent mothers consume FV less frequently and UPF more frequently than adult mothers, and thus offer similar food to their children ${ }^{38}$. Even infants with mothers between 20 and 35 years old had a lower prevalence of FV and higher of UPF that infants of women over 35. Such a finding may be explained by the fact that older adults are more concerned with health and food issues than younger adults, and thus, offering more FV and less UPF to their children.

FV consumption was less prevalent and UPF was more prevalent among infants born to multiparous women, although with a small magnitude. Studies that evaluated dietary patterns found a negative dose-response relationship of diet characterized by more healthy foods with infant's birth order ${ }^{25}$, and with infants with greater number of siblings ${ }^{26}$, along with a positive dose-response relationship of diet characterized by unhealthy foods with infant's birth order ${ }^{25}$, with increased parity ${ }^{36}$ and with infants with greater number of siblings ${ }^{26}$. Study carried out in Pelotas, RS, found high availability of FV and low availability of soft drinks, sweets, packaged snacks, and frozen foods in households with only adults compared to households with children ${ }^{18}$. One possible explanation for the effect of parity in the present study is that, among children of multiparous women, the priorities and dietary needs of older children compete with those of younger children ${ }^{25}$, reducing the likelihood of an adequate diet for the infant ${ }^{36}$.

Maternal work status lost statistical significance in the multiple analysis for consumption of UPF; nevertheless, infants born to stay-athome mothers had a lower prevalence of FV consumption. Other studies that evaluated infant food consumption had similar findings $s^{27,39,40}$; one found that mothers who worked outside the home had nearly twice the chance of offering FV to their children ${ }^{39}$; and another one found that among children of women who worked outside the home, the chance of consuming vegetables and fruits was 2.7 and 4.2 times, respectively, in relation to the offspring of mothers who did not work outside the home ${ }^{40}$. Working outside the home may be related to both higher family income and greater access to information on foods that are part of a healthier diet ${ }^{27,40}$.

A positive dose-response relationship was found between birth weight and prevalence of UPF consumption. Although this result was small in magnitude, it is still concerning, and a systematic review found a positive association between birth weight and childhood obesity ${ }^{41}$. This finding shows that while mothers of children born with low birth weight should be given priority in guidelines related to infant feeding and nutrition, mothers of children born with high birth weight also need to receive adequate information about infant feeding.

Infants who received outpatient care in the public health network had lower prevalence of FV consumption, and higher prevalence of UPF consumption. Sotero et al. ${ }^{28}$ studied infants less than 24 months old in the city of Maceió (state of Alagoas, Brazil) and observed less prevalent of FV consumption and more prevalent consumption of unhealthy foods (artificial juices, soft drinks, processed sweets, cookies, and packaged snacks) among those who received outpatient care in the public health network compared to infants who received outpatient care in the private network. They also found lower consumption of FV and higher consumption of unhealthy foods among infants belonging to lower income families. Considering that the population who receives outpatient healthcare in the public network is generally low income, measures should be adopted that make FV more accessible and UPF less accessible to the less affluent population. Moreover, primary healthcare professionals should prioritize actions to promote health ${ }^{28}$, including those related to increasing the consumption of 
healthy foods and reducing the consumption of UPF. The study of Vitolo et al. ${ }^{42}$ found that nutritional counseling for mothers during the first year of an infant's life improved the overall quality of their diet. However, the performance of the multi-professional health team could be focused on achieving goals and meeting excess demand, which could damage the quality of care provided to the population ${ }^{28}$.

The multilevel analysis showed that, after controlling for individual level variables, the prevalence of FV consumption decreased and UPF increased with decreased population size. For UPF, population size did not reach statistical significance, but showed a trend close to the established cut-off point. In the state of São Paulo, municipalities with a smaller population tend to be poorer; in 2008, most municipalities with less than 15 thousand inhabitants were considered as the most disadvantaged and with low levels of wealth, while those with more than one million inhabitants were classified as having high levels of wealth ${ }^{43}$. Small towns have a high proportion of convenience stores, which are small stores with mostly ready-to-eat foods (which have high energy density) and a limited supply of fresh foods. In general, convenience stores have been found to serve less healthy food options than supermarkets $^{7,44}$. Moreover, more fast food restaurants has been observed in smaller towns with low socioeconomic status ${ }^{44,45}$. Pessoa et al..$^{46}$ found higher FV intake scores in neighborhoods with higher density of healthy food outlets and higher income, and lower scores in neighborhoods with higher density of unhealthy food outlets. Duran et al. ${ }^{45}$ observed, in the city of São Paulo, that fast food restaurants and local grocery stores were more likely to be located in low socioeconomic status neighborhoods. Thus, a high proportion of convenience stores in the neighborhood, predominantly selling convenient and energy-dense food, might initiate unhealthy eating patterns ${ }^{47}$ and may lead to increased Body Mass Index in children compared to neighborhoods with less access to these stores ${ }^{44}$.

Compared to other food stores, large supermarket and grocery store chains tend to offer greater variety of healthy foods ${ }^{45}$ with lower pric$\mathrm{es}^{48}$, which may contribute to the consumption of these foods. However, UPF are not just found in convenience stores and fast food restaurants; in large chain supermarkets, natural or minimally processed foods share space, at immense disadvantage, with UPF, which are usually accompanied by advertisements, discounts, and promo- tions, to stimulate their consumption. Machado et al. ${ }^{49}$ evaluated the association between food stores and consumption of UPF in Brazil, and found that the price of these foods was lower at supermarkets than at other food stores. Moreover, thousands of branded UPF are available in many places where food was usually not sold, such as pharmacies, gas stations, news-stands, and hospitals; all these points of sale also facilitate the access to these foods ${ }^{5}$.

Considering that healthy foods are often perishable, the differences in relation to the food distribution system between smaller and larger cities may influence food consumption. Martin et al. ${ }^{50}$ evaluated the quality of fresh produce and the size of stores that sell food in an American city and found that smaller stores offer lower quality fresh produce compared to larger supermarkets. Pessoa et al. ${ }^{46}$ observed that FV are less available or are lower quality in lower income areas. Thus, fresh and healthy products may be available in small municipalities, but the lower quality may hinder their purchase and consumption. Although the present study did not evaluate the types of food stores in each municipality, nor in which places the adult responsible for infants purchased food but considering that food consumption is determined by factors such as physical and financial availability of foods ${ }^{50}$, the dose-response relationship observed between population size and consumption of FV and UPF suggests possible mechanisms for these findings. Future research should explore contextual determinants of food consumption in infants under one year old.

Limitations of the study include its cross-sectional design, which prevents establishment of causal relationships, and the fact that the feeding information referred only to the day before the survey. However, one of the innovative aspects of the present study was the use of a multilevel regression analysis model, a technique that has rarely been applied to studies on infant feeding. This approach is most suited to research involving hierarchical data and to explain the effect of individual and contextual variables as determinants of infant feeding ${ }^{51}$. Moreover, considering that the state of São Paulo has many social and economic disparities ${ }^{52}$, it is believed that the findings of the present study can be extrapolated to other regions of the country as well as to other countries with similar characteristics. The SBP2008 is the most recent epidemiological study representing this population of infants conducted in Brazil, meaning it is the most up-to-date database to evaluate infant feeding. 
The present study identified some groups of infants from the state of São Paulo who are susceptible to lower and higher prevalence of consumption of FV and UPF, respectively. Socioeconomic status was shown to be an important factor associated with infant feeding, as could be observed among infants born to women with low education levels, who received outpatient care in the public health network, and who reside in small municipalities. Thus, these groups should be prioritized in public policies for nutritional educational on food in the first year of life, considering the accelerated speed of growth and development during this period. In addition, the continuous monitoring of infant feeding practices is necessary through population-based surveys, to analyze the trend of the indicators and to study other possible determinants and outcomes of this population's food consumption.

\section{Collaborations}

All authors participated substantially in the preparation of this manuscript - conception and design of the article, discussion of the theme and relevant critical review of intellectual content and all revised the final version of the document, approving it for submission. 


\section{References}

1. World Health Organization (WHO). The optimal duration of exclusive breastfeeding: a systematic review. Geneva: WHO; 2002.

2. World Health Organization (WHO). Global strategy for infant and young child feeding. Geneva: WHO; 2003.

3. Beauchamp GK, Menella JA. Early flavor learning and its impact on later feeding behavior. J Pediatr Gastroenterol Nutr 2009; 48(Supl. 1):25-30.

4. Brasil. Ministério da Saúde (MS). Dez passos para uma alimentação saudável: guia alimentar para menores de dois anos - um guia para o profissional da saúde na atenção básica. $2^{\mathrm{a}}$ ed. Brasília: MS; 2010.

5. Brasil. Ministério da Saúde (MS). Guia alimentar para a população brasileira. 2a ed. Brasília: MS; 2014.

6. Monteiro CA, Cannon G, Moubarac JC, Levy RB, Louzada MLC, Jaime PC. The UN Decade of Nutrition, the NOVA food classification and the with ultra-processing. Public Health Nutr 2017; 21(1):1-13.

7. Larson N, Story M. A review of environmental influences on food choices. Ann Behav Med 2009; 38(Supl. 1):56-73.

8. Brasil. Ministério da Saúde (MS). Pesquisa de Prevalência de Aleitamento Materno em Municípios Brasileiros. Brasília: MS; 2010.

9. Passanha A, Benício MHDA, Venâncio SI. Influence of breastfeeding on consumption of sweetened beverages or foods. Rev Paul Pediatr 2018; 36(2):148-154.

10. Barros AJD, Hirakata VN. Alternatives for logistic regression in cross-sectional studies: an empirical comparison of models that directly estimate the prevalence ratio. BMC Med Res Methodol 2003; 3:21.

11. Victora CG, Huttly SR, Fuchs SC, Olinto MTA. The role of conceptual frameworks in epidemiological analysis: a hierarchical approach. Int J Epidemiol 1997; 26(1):224-227.

12. Venâncio SI, Monteiro CA. Individual and contextual determinants of exclusive breast-feeding in São Paulo, Brazil: a multilevel analysis. Public Health Nutr 2006; 9(1):40-46

13. Snijders TAB, Bosker RJ. Multilevel analysis: an introduction to basic and advanced multilevel modeling. $2^{\mathrm{a}}$ ed. London: Sage; 2012.

14. Levy-Costa RB, Sichieri R, Pontes NS, Monteiro CA. Disponibilidade domiciliar de alimentos no Brasil: distribuição e evolução (1974-2003). Rev Saúde Pública 2005; 39(4):530-540.

15. Levy RB, Claro RM, Mondini L, Sichieri R, Monteiro CA. Distribuição regional e socioeconômica da disponibilidade domiciliar de alimentos no Brasil em 20082009. Rev Saúde Pública 2012; 46(1):6-15

16. Monteiro CA, Levy RB, Claro RM, Castro IRR, Cannon G. Increasing consumption of ultra-processed foods and likely impact on human health: evidence from Brazil. Public Health Nutr 2011; 14(1):5-13.

17. Martins APB, Levy RB, Claro RM, Moubarac JC, Monteiro CA. Participação crescente de produtos ultraprocessados na dieta brasileira (1987-2009). Rev Saúde Pública 2013; 47(4):656-665.

18. Soares ALG, França GVA, Gonçalves H. Household food availability in Pelotas, Brazil: an approach to assess the obesogenic environment. Rev Nutr 2014; 27(2):193-203.
19. Ministério da Saúde (MS). II Pesquisa de Prevalência de Aleitamento Materno nas Capitais Brasileiras e Distrito Federal. Brasília: MS; 2009.

20. Jaime PC, Frias PG, Monteiro HOC, Almeida PVB Malta DC. Assistência em saúde e alimentação não saudável em crianças menores de dois anos: dados da Pesquisa Nacional de Saúde, Brasil, 2013. Rev Bras Saúde Matern Infant 2016; 16(2):159-167.

21. Jordão RE, Bernardi JLD, Filho AAB. Introdução alimentar e anemia em lactentes do município de Campinas (SP). Rev Paul Pediatr 2009; 27(4):381-388.

22. Stevens LJ, Kuckzek T, Burgess JR, Stochelski MA, Arnold LE, Galland L. Mechanisms of behavioral, atopic, and other reactions to artificial food colors in children. Nutr Rev 2013; 71(5):268-281.

23. Barcelos GT, Rauber F, Vitolo MR. Produtos processados e ultraprocessados e ingestão de nutrientes em crianças. Rev Ciên Saúde 2014; 7(3):155-161.

24. Rose CM, Birch LL, Savage JS. Dietary patterns in infancy are associated with child diet and weight outcomes at 6 years. Int J Obes (London) 2017; 41(5):783788.

25. Robinson S, Marriott L, Poole J, Crozier S, Borland S, Lawrence W, Law C, Godfrey K, Cooper C, Inskip H, Southampton Women's Survey Study Group. Dietary patterns in infancy: the importance of maternal and family influences on feeding practice. Br J Nutr 2007; 98(5):1029-1037.

26. Smithers LG, Brazionis L, Golley RK, Mittinty MN, Northstone K, Emmett P, McNaughton SA, Campbell KJ, Lynch JW. Associations between dietary patterns at 6 and 15 months of age and sociodemographic factors. Eur J Clin Nutr 2012; 66(6):658-666.

27. Ducci AL, Vannuchi MTO, Souza SNDH, Tacla MTGM, Lima LS. Aleitamento materno e consumo alimentar de crianças menores de um ano em um município do Sul do Brasil. Rev Bras Pesq Saúde 2013; 15(1):49-58.

28. Sotero AM, Cabral PC, Silva GAP. Fatores socioeconômicos, culturais e demográficos maternos associados ao padrão alimentar de lactentes. Rev Paul Pediatr 2015; 33(4):445-452.

29. Saldiva SRDM, Venâncio SI, Santana AC, Castro ALS, Escuder MML, Giugliani ERJ. The consumption of unhealthy foods by Brazilian children is influenced by their mother's educational level. Nutr J 2014; 13:33.

30. Khanal V, Sauer K, Zhao Y. Determinants of complementary feeding practices among Nepalese children aged 6-23 months: findings from demographic and health survey 2011. Pediatrics 2013; 13:131.

31. Moubarac JC, Claro RM, Baraldi LG, Levy RB, Martins APB, Cannon G, Monteiro CA. International differences in cost and consumption of ready-to-consume food and drink products: United Kingdom and Brazil, 2008-2009. Glob Public Health 2013; 8(7):845856.

32. Claro RM, Monteiro CA. Renda familiar, preço dos alimentos e aquisição domiciliar de frutas e hortaliças no Brasil. Rev Saúde Pública 2010; 44(6):1014-1020.

33. Monteiro CA, Moubarac JC, Cannon G, Ng SW, Popkin B. Ultra-processed products are becoming dominant in the global food system. Obes Rev 2013; 14(Supl. 2):21-28. 
34. Nederkoorn C, Havermans RC, Giesen JCAH, Jansen A. High tax on high energy dense foods and its effects on the purchase of calories in a supermarket. An experiment. Appetite 2011; 56(3):760-765.

35. Hendricks K, Briefel R, Novak T, Ziegler P. Maternal and Child Characteristics Associated with Infant and Toddler Feeding Practices. J Am Diet Assoc 2006; 106(Supl. 1):135-148.

36. Betoko A, Charles MA, Hankard R, Forhan A, Bonet M, Saurel-Cubizolles MJ, Heude B, Lauzon-Guillain B, EDEN mother-child cohort study group. Infant feeding patterns over the first year of life: influence of family characteristics. Eur J Clin Nutr 2013; 67(6):631-637.

37. Fuzeto KLR, Oliveira ACL. Comparação da prática do aleitamento materno e da alimentação complementar entre mães adolescentes e adultas, Curitiba/PR. Cad Escola Saúde 2010; 1(3):1-16.

38. Lima APE, Javorski M, Vasconcelos MGL. Práticas alimentares no primeiro ano de vida. Rev Bras Enferm 2011; 64(5):912-918.

39. Correa EN, Corso ACT, Moreira EAM, Kazapi IAM. Alimentação complementar e características maternas de crianças menores de dois anos de idade em Florianópolis (SC). Rev Paul Pediatr 2009; 27(3):258-264.

40. Campagnolo PDB, Louzada MLC, Silveira EL, Vitolo MR. Práticas alimentares no primeiro ano de vida e fatores associados em amostra representativa da cidade de Porto Alegre, Rio Grande do Sul. Rev Nutr 2012; 25(4):431-439.

41. Martins EB, Carvalho MS. Associação entre peso ao nascer e o excesso de peso na infância: revisão sistemática. Cad Saúde Pública 2006; 22(11):2281-2300.

42. Vitolo MR, Rauber F, Campagnolo PDB, Feldens CA, Hoffman DJ. Maternal dietary counseling in the first year of life is associated with a higher healthy eating index in childhood. J Nutr 2010; 140(11):2002-2007.

43. Fundação Sistema Estadual de Análise de Dados. Perfil dos Municípios Paulistas [Internet]. 2018 [acessado 2018 Jul 16]. Disponível em: http://www.perfil.seade. gov.br

44. Galvez MP, Hong L, Choi E, Liao L, Godbold J, Brenner B. Childhood obesity and neighborhood food-store availability in an inner-city community. Acad Pediatr 2009; 9(5):339-343.
45. Duran AC, Diez-Roux AV, Latorre MRDO, Jaime PC. Neighborhood socioeconomic characteristics and differences in the availability of healthy food stores and restaurants in São Paulo, Brazil. Health Place 2013; 23:39-47.

46. Pessoa MC, Mendes LL, Gomes CS, Martins PA, Velasquez-Melendez G. Food environment and fruit and vegetable intake in an urban population: a multilevel analysis. BMC Public Health 2015; 15:1012.

47. Lind PL, Jensen PV, Glümer C, Toft U. The association between accessibility of local convenience stores and unhealthy diet. Eur J Public Health 2016; 26(4):634639.

48. Lee RE, Heinrich KM, Medina AV, Regan GR, Reese -Smith JY, Jokura Y, Maddock JE A picture of the healthful food environment in two diverse urban cities. Environ Health Insights 2010; 4:49-60.

49. Machado PP, Claro RM, Canella DS, Sarti FM, Levy RB. Price and convenience: the influence of supermarkets on consumption of ultra-processed foods and beverages in Brazil. Appetite 2017; 116:381-388.

50. Martin KS, Ghosh D, Page M, Wolff M, McMinimee $\mathrm{K}$, Zhang $\mathrm{M}$. What role do local grocery stores play in urban food environments? A case study of HartfordConnecticut. PLoS One 2014; 9(4):e94033.

51. Wenzel D, Ocaña-Riola R, Maroto-Navarro G, Souza SB. A multilevel model for the study of breastfeeding determinants in Brazil. Matern Child Nutr 2009; 6(4):318-327.

52. Dedecca CS. Por dentro do estado de São Paulo. Novos estudos - CEBRAP 2009; 84:127-150.

Article submitted 05/12/2018

Approved 15/04/2019

Final version submitted 17/04/2019

Chief Editors: Romeu Gomes, Antônio Augusto Moura da Silva 